\title{
International Metallographic Society
}

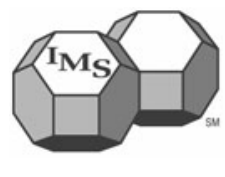

\section{Message from the President}

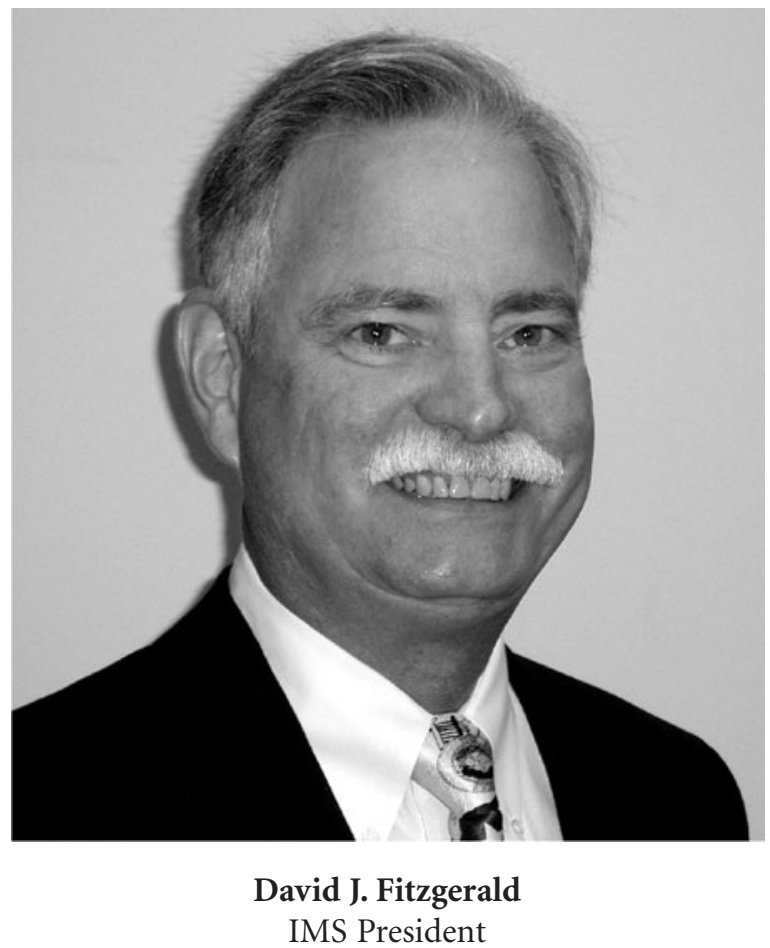

On behalf of the International Metallographic Society, welcome to Albuquerque for Microscopy \& Microanalysis 2008, the premier event in our scientific field. IMS is pleased to again join the Microscopy Society of America and the Microbeam Analysis Society to offer a unique combination of Scientific Content, Exhibitions and most fun of all, the gathering of our peers involved in the field of studying the very small. This meeting represents the 41st Annual Event for IMS, and the seventh year that we have joined in the M\&M Event.

Our Short Courses include "Metallographic Interpretation for Medical Devices" by Gabe Lucas and Fred Schmidt, "Failure Analysis and Evidence Preservation by Metallography" by Fred Schmidt, and "How to Organize and Run a Failure Investigation” by Daniel Dennies.

Once again our Special Event will be the IMS Henry Clifton Sorby Award Lecture, presented by this year's Awardee Dr. Lawrence Murr of the University of Texas. Dr. Murr has contributed to the IMS Technical Event for many years, and we look forward to an interesting and informative presentation. We have moved the Sorby Lecture to the early afternoon on Monday, so be sure to look for this lecture within the Symposia.

We are presenting Physical Science Symposia, including "Metallographic Techniques and Material Characterization" chaired by Rick Noeker and Nat Saenz, "Image Analysis and Quantitative Microscopy" chaired by Rob Panaro and Don Susan, "Failure Analysis: Real World Applications and Case Studies" chaired by Daniel Dennies and Fred Schmidt, and "Nuclear and Reactive Materials" chaired by Ian Davidson and

\section{IMS CALENDAR OF EVENTS 2008}

Saturday, August 2, 2008

IMS Board Meeting, 8:00 AM-5:00 PM (Pecos)

IMS Poster Judging, 8:00 AM-5:00 PM (Pecos)

IMS Ice-Breaker Reception, 7:30 PM (Hyatt Regency Albuquerque)

Sunday, August 3, 2008

Sunday Evening Social Event (Rio Grande Zoo) (for details see Page 19), 6:30 PM-9:30 PM

Monday, August 4, 2008

IMS Henry Clifton Sorby Award and Lecture, 11:00 AM-12:00 PM (Pecos)

Student Mixer, 5:15-6:15 PM (Centro del Sol)

Wednesday, August 6, 2008

IMS General Members Meeting, 12:15-1:15 PM (Pecos)

IMS Awards Banquet, 6:30 PM (National Hispanic Cultural Center, Ticket required, visit the IMS Booth for information)

Allan Lockley. In the area of Advances in Instrumentation \& Techniques Symposia we are pleased to offer "Microscopy Techniques for Ceramics and Composites" chaired by Erica Corral, Luther Gammon, and Bryan Gaunt.

Be sure to plan a visit to the outstanding posters displayed in the exhibition area showing this years entries in the IMS International Metallographic Contest. The IMC allows scientists to compete for monetary prizes in 11 classes, with the Best in Show winning the Jacquet-Lucas Award, which includes a cash award of $\$ 3000$.

So as you can see, when combined with the outstanding offerings from MSA and MAS, we have an exciting week in the Southwest!

\section{IMS BOARD OF DIRECTORS}

\begin{tabular}{ll}
\hline President: & David J. Fitzgerald \\
Vice President: & Frauke Hogue \\
Financial Officer: & Richard A. Blackwell \\
Secretary: & Thomas F. Murphy \\
Past President: & Dennis W. Hetzner \\
Directors: & Judith L. Arner \\
& Steven J. Dekanich \\
& Jaret J. Frafjord \\
& Gabriel M. Lucas \\
& Natalio T. Saenz \\
& Donald F. Susan \\
Board Liaison: & Daniel P. Dennies
\end{tabular}




\section{IMS Appointed Officers}

Editor, Materials Characterization Chris Bagnall

Executive Director
Thomas S. Passek
Administrator of Affiliate Societies Sarina Pastoric

SlipLines Managing Editor Ed Kubel

\section{imS Corporate Sponsors}

IMS Benefactors Buehler Ltd.

Carl Zeiss Microimaging, Inc.

Elsevier

IMS Patrons Allied High Tech Products, Inc.

Precision Surfaces International

Struers Inc.

\author{
IMS Associates LECO Corp. \\ B\&W Technical Services Y-12 \\ Carl Zeiss SMT, Inc. \\ Metallurgical Supply Company, Inc.
}

IMS Sponsors MetLab Corp.

Nikon Instruments

\section{Past Presidents}

$\begin{array}{ll}1968-1971 & \text { John H. Bender Jr. } \\ 1971-1973 & \text { Arthur E. Calabra } \\ 1973-1975 & \text { E. Daniel Albrecht } \\ 1975-1977 & \text { James H. Richardson } \\ 1977-1979 & \text { Robert J. Gray } \\ 1979-1981 & \text { P.M. French } \\ 1981-1983 & \text { George Vander Voort } \\ 1983-1985 & \text { James E. Bennett } \\ 1985-1987 & \text { William E. White } \\ 1987-1989 & \text { M.R. Louthan, Jr. }\end{array}$

1968-1971 John H. Bender Jr.

1975-1977 James H. Richardson

1977-1979 Robert J. Gray

1981-1983 George Vander Voort

1985-1987 William E. White

\section{History of the IMS Awards}

Henry Clifton Sorby AwArd-The Sorby Award was established to recognize outstanding contributions to the field of metallography by an internationally recognized senior figure in the field of metallography. This award is a personalized plaque, and the recipient is honored during the M\&M Conference Sorby lecture and at the IMS Annual Meeting banquet.

Pierre Jacquet-Francis F. Lucas Award-The Jacquet-Lucas award is given each year to the International Metallographic Contest entry judged "Best in Show" by a panel of judges. This is a joint IMS/ASM award with origins dating back to 1946, and has been endowed by Buehler Ltd. since 1976. The winner receives \$3000, the Jacquet Gold Medal, the ASM Lucas Award, and is honored at banquets at both the IMS Annual Meeting and the ASM Annual Event.

President's AwARD-This award is presented to an individual deemed deserving of special recognition by the Society. This award is a plaque personalized for the recipient.
1989-1991 Donald W. Stevens
1991-1993 Iain LeMay
1993-1995 Japnell D. Brown
1995-1997 E. Daniel Albrecht
1997-1999 Mahmoud T. Shehata
1999-2001 Elliot A. Clark
2001-2003 Richard K. Ryan
2003-2005 Allan J. Lockley
2005-2007 Dennis W. Hetzner

Buehler Technical Paper Merit Award-This award shall be given annually to the authors of the technical paper published that year in the journal Materials Characterization that was determined most outstanding by a panel of IMS judges. A plaque and cash award is given to the recipients each year by Buehler Ltd.

Past-Presidents AwArd-This award shall be presented by the Board of Directors to the out-going Past-President in recognition of their contributions to the Society. This award is a plaque personalized for the recipient.

Presentation of the IMS Awards - The awards are presented at the annual banquet Wednesday, August 6, 2008, at 6:30 PM. 


\author{
President's Award \\ (Service to IMS) \\ 1977 \\ 1978 \\ 1979 \\ 1980 \\ 1981 \\ 1982 \\ 1983 \\ 1984 \\ 1985 \\ 1986 \\ 1987 \\ 1988 \\ 1989 \\ 1990 \\ 1991 \\ 1992 \\ 1993 \\ 1994 \\ 1995 \\ 1996 \\ 1997 \\ 1998 \\ 1999 \\ 2000 \\ 2001 \\ 2002 \\ 2003 \\ 2004 \\ 2005 \\ 2006 \\ 2007 \\ Carus K.H. DuBose \\ Richard D. Buchheit \\ Arthur E. Calabra \\ James L. McCall \\ E. Daniel Albrecht \\ James H. Richardson \\ Robert J. Gray \\ Japnell D. Braun \\ Not Given \\ P. Michael French \\ George F. Vander Voort \\ Robert S. Crouse \\ Iain Le May \\ William E. White \\ Chris Bagnall \\ Gary W. Johnson \\ Donald W. Stevens \\ MacIntyre R. Louthan, Jr. \\ Gunter Petzow \\ James Nelson \\ John Wylie \\ John W. Simmons \\ William Forgeng, Jr. \\ Natalio Saenz \\ William W. Scott, Jr. \\ George Blann \\ Jeff Stewart \\ Elliot A. Clark \\ Chris Bagnall \\ Art Geary \\ Richard K. Ryan
}

Henry Clifton Sorby Awards

George L. Kehl

Cyril Stanley Smith

Adolph Buehler

Frederick N. Rhines

Len E. Samuels

Robert J. Gray

Gunter Petzow

William D. Forgeng

Ervin E. Underwood

Alan Price

Robert W. K. Honeycombe

Gareth Thomas

Franz Jeglitsch

Tanjore R. Anantharaman

E. Daniel Albrecht

W.C. Leslie

Charles S. Barrett

Raimond B. Castaing

F. Brian Pickering

Erhard Hornbogen
1996 Peter Duncumb

1997 Robert T. DeHoff

1998 Kay Geels

1999 Joseph Goldstein

2000 Hans Eckhart Exner

2001 Brian Ralph

2002 Walter Mannheimer

2003 Enrica Stagno

2004 George F. Vander Voort

2005 Iain LeMay

2006 Arlen Benscoter

2007 McIntyre R. Louthan, Jr.

International

Metallographic Contest

1946 G.R. Kuhn

1947 R.H. Hays

1948 E.C. Pearson

1949 D.H. Rowland

1950 S.O. Modin

1951 H.P. Roth

1952 H. Griffin

1953 B.C. Leslie, R.J. Gray

1954 R.D. Buchheit, J.E. Boyd,

A.A. Watts, F.C. Holden

1955 F.M. Cain, Jr.

1956 D. Mannas

1957 T.K. Bierlein, B. Mastel

Francis F. Lucas

Metallographic Award

1958

J.C. Gower, E.P. Griggs,

W.E. Denny, J.E. Epperson, R.J. Gray

1959 F.M. Beck

1960 G.C. Woodside

1961 J.F. Radavich, W. Couts, Jr.

1962 D. Medlin

1963 W.C. Coons

1964 B.C. Leslie, R.J. Gray

1965 W.C. Coons, A. Davinroy

1966 D.M. Maher, A. Eikum

1967 J.F. Kisiel

1968 R.M.N. Pelloux, H. Wallner

1969 R.H. Beauchamp, R.P. Nelson

1970 D.R. Betner, W.D. Hepfer

1971 R.J. Gray

Pierre Jacquet Award

1968 L.R. Salvage

1969 S. DiGiallonardo,

R.R. VanderVoort

1970 G. Menke

1971 R.H. Beauchamp, J.F. Williford
Jacquet-Lucas Metallographic Award

1972 C.J. Echer, S.L. DiGiallonardo

1973 M.S. Grewal, B.H. Alexander, S.A. Sastri

1974 M.P. Pinnel, D.E. Heath, J.E. Bennett, G.V. McIlharagie

1975 W.C. Coons

1976 L.E. Soderqvist

1977 R.H. Beauchamp, D.H. Parks, N.T. Saenz, K.R. Wheeler

1978 C. Bagnall, R. Witkowski

1979 M.J. Bridges, S.J. Dekanich

1980 R.H. Beauchamp, K. Fredriksson

1981 F. Kurosawa, I. Taguchi, H.G. Suzuki

1982 M.J. Carr, M.C. Mataya, T.O. Wilford, J.L. Young

1983 V. Carle, E. Schmid

1984 R.H. Beauchamp, N.T. Saenz, J.T. Prater

1985 U. Taffner, R. Telle

1986 N.T. Saenz, C.A. Lavender, M.T. Smith, D.H. Parks, G.M. Salazar

1987 S.A. David, J.M. Vitek, C.P. Haltom, A.G. Barcomb

1988 A. David, J.M. Vitek, A. Boatner, G.C. Marsh, A.B. Baldwin

1989 G. Hoerz, M.C. Kallfass

1990 A. David, J.M. Vitek, A.B. Baldwin

1991 M.R. Jones

1992 G.F. VanderVoort

1993 T. Leonhardt, F. Terepka, M. Singh, G. Soltis

1994 J.W. Simmons, B.S. Covino, Jr., S.D. Cramer, J.S. Dunning

1995 Kamal, K. Soni, R. Levi-Setti, S. Shah, S.J. Gentz

1996 R.L. Bodnar, S.J. Lawrence

1997 J. Yewko, D.L. Marshall

1998 R. Pereyra, E.G. Zukas

1999 K.R. Luer

2000 D.J. Lewis, S. Allen

2001 D. Chakrapani

2002 F.F. Noecker, II

2003 F.F. Noecker, II

2004 R. Unocic, P.M. Sarosi, M.J. Mills

2005 K. Kimura, S. Hata, S. Matsumura, T. Horiuchi

2006 Ryan Deacon

2007 K.A. Unocic, G.S. Daehn 


\section{Jacquet-Lucas Award}

In the 2007 International Metallographic Contest, the Jacquet-Lucas award was awarded to the entry titled: "TEM Sample Preparation Method for Grain Boundary Phase Identification in Al-Mg Alloys." This exceptional display of metallography combined traditional chemical etching with focused ion beam (FIB) milling, and came about through the combined efforts Ms. Kinga Unocic and Prof. Glenn S. Daehn from the Department of Materials Science and Engineering, Ohio State University, Columbus, Ohio.

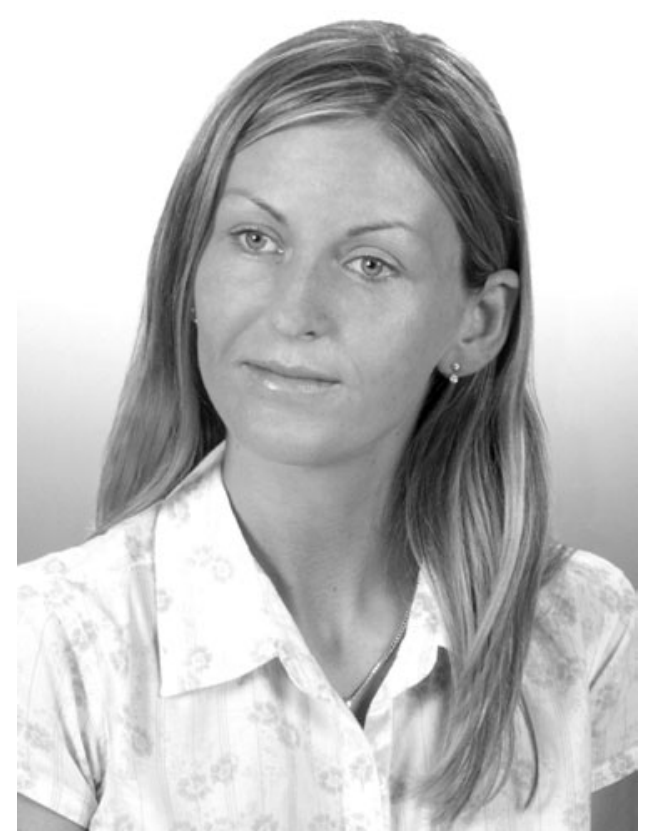

IMS Jacquet Lucas Award Kinga A. Unocic

Kinga A. Unocic is a Ph.D. student in the Materials Science and Engineering Department at the Ohio State University working with Professors Glenn Daehn and Michael Mills. Originally from Oswiecim Poland, she graduated from AGH-University of Science and Technology in Krakow, Poland, in 2002 with a MS degree in Metallurgy, where she also received an award for scholar athlete of the year in 1998/99. She was a visiting research scholar at Lehigh University in Bethlehem, PA, where she conducted research on extrusion of 6xxx series aluminum alloys with the Institute for Metal Forming group under the guidance of Professor Wojciech Misiolek. Her current research is focused on alloy development of 5xxx series aluminum alloys for improved intergranular corrosion resistance and her research interests include the use of materials characterization techniques (SEM, TEM, FIB) to explore the relationship between microstructure, corrosion, and mechanical properties.

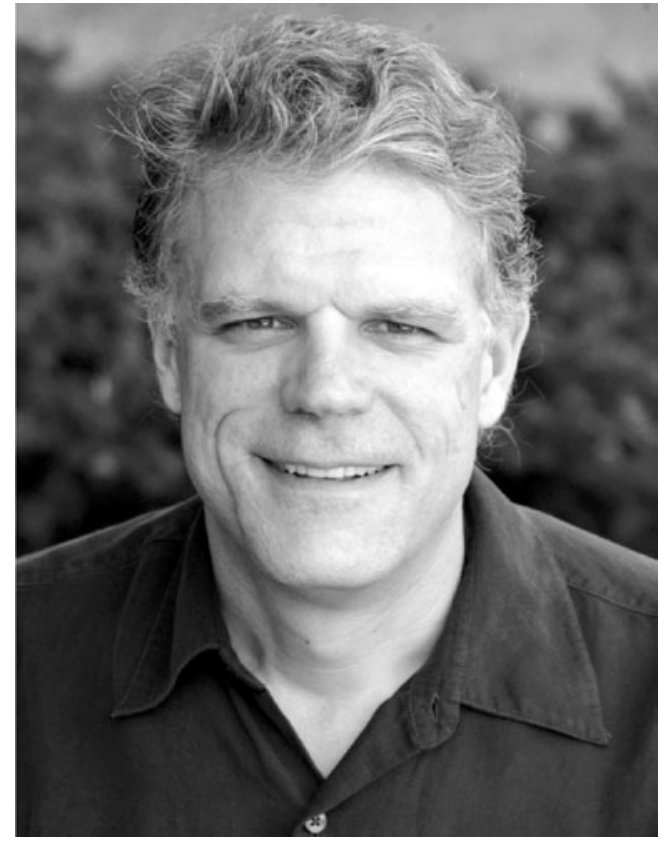

IMS Jacquet Lucas Award Glenn S. Daehn

Glenn S. Daehn is the Mars G. Fontana Professor of Metallurgical Engineering in the Department of Materials Science and Engineering at The Ohio State University, Columbus, $\mathrm{OH}$. He carries out research in three principal areas: high velocity and impulse methods for metal forming, the high temperature deformation of metals, and the processing of metals and ceramic-metal composites. He is also active in programs to bring materials science to high school students through new or improved courses. Prior awards include the ASM Grossman Young Author Award, the TMS Hardy Medal and he was named a National Young Investigator of The National Science Foundation. Glenn received his BS from Northwestern University and $\mathrm{PhD}$ and MS were granted from Stanford University, all in Materials Science and Engineering. 


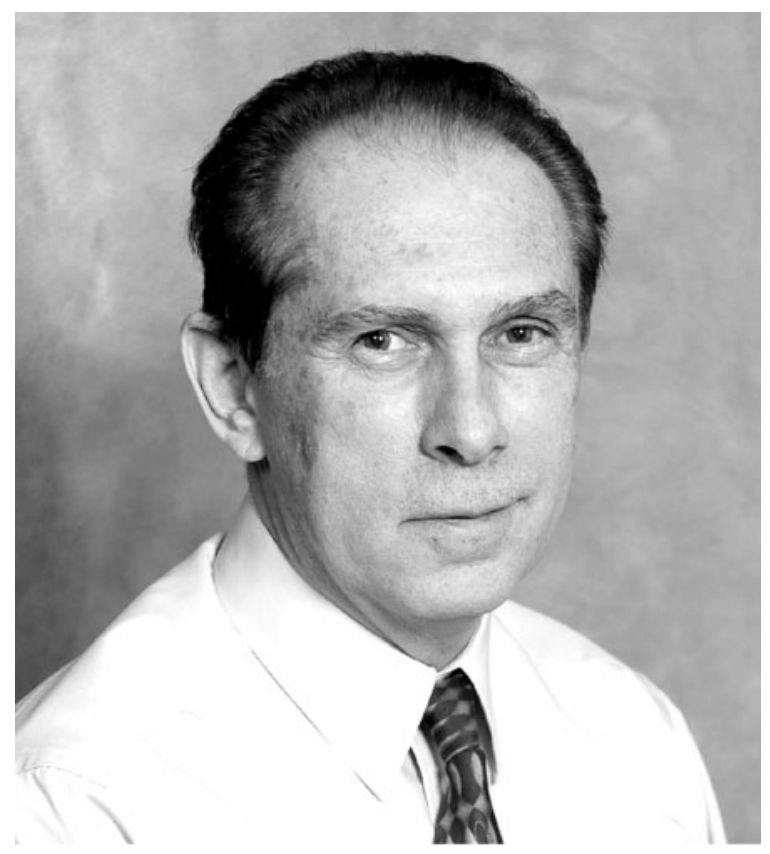

Henry Clifton Sorby Award

Lawrence E. Murr

Lawrence E. Murr is Mr. \& Mrs. MacIntosh Murchison Professor and Chairman of the Department of Metallurgical and Materials Engineering and Ph.D. Program Director in the Materials Research \& Technology Institute at The University of Texas at El Paso. Dr. Murr received his B.Sc. in physical science from Albright College, and his B.S.E.E. in electronics, his M.S. in engineering mechanics, and his Ph.D. in solid-state science, all from the Pennsylvania State University. Dr. Murr has taught at the Pennsylvania State University, the University of Southern California, New Mexico Institute of Mining and Technology, and the Oregon Graduate Institute of Science and Technology. He was Director of the John D. Sullivan Center for In-Situ Mining Research, President of the New Mexico Tech Research Foundation, and Professor and Head of the Metallurgical and Materials Engineering Department at New Mexico Institute of Mining and Technology. He was a past Chairman of the New Mexico Joint Center for Materials Science and served as Vice President for Academic Affairs and Research and Director of the Office of Academic and Research Programs at the Oregon Graduate Institute, where he was also Professor of Materials Science and Engineering.

Dr. Murr has published 20 books, over 700 scientific and technical articles in a wide range of research areas in materials science and engineering, environmental science and engineering, manufacturing science and engineering, and biological science and engineering. Recent honors include the 2001 Buehler Technical Paper Merit Award for Excellence (IMS), the TMS 2007 Educator Award, and the 2007 John S. Rinehart Award (a TMS Symposium award). Professor Murr is also a Fellow of ASM International.

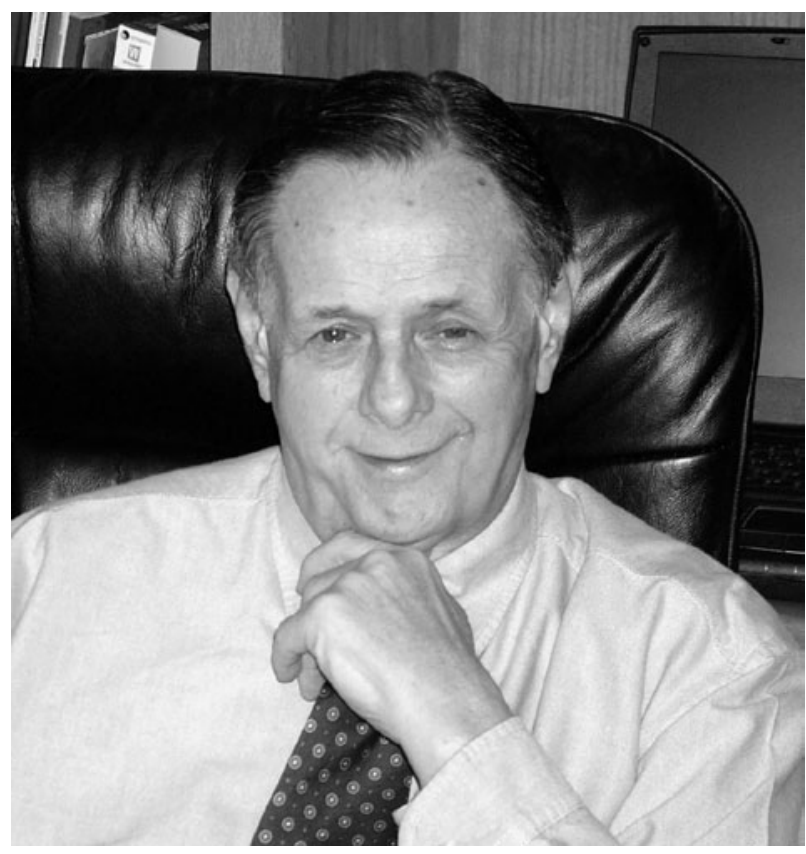

President's Award

Richard (Dick) K. Ryan

Richard (Dick) K. Ryan has been active with IMS as a Charter member, joining at the Society's inception in 1968 . He served as a Board Member, Officer, and as its President from 2001-2003. Dick was also very active in ASM International where he served as a Chapter Chairman and on many national committees including the Publications Council which he chaired for two years. Dick was honored as a Fellow of ASM in 1998.

His professional career was spent entirely with Buehler Ltd. (1957-2002) where he served in various capacities. He started in the Metallographic Laboratory, was promoted to Sales Engineer (1959-1970) and held various management positions during subsequent years. Dick was awarded the Masters of Business Administration Degree from Lake Forest Graduate School of Management in 1983. During the last twelve years of his working career, he held the position of Executive Vice-President of Buehler Ltd.

\section{THE 2007 INTERNATIONAL Metallographic Contest JUDGING TEAM}

Chair: Jeff Stewart, Stern-Leach Company

Local Chair: Alice Kilgo, Sandia National Labs

Members: Steve Glancy, Struers Inc.

Tom O'Connell, HEICO Aerospace

Brian Rose, Arvin-Meritor Inc.

Tim Weber, Buehler Ltd. 


\section{IMS 2008 Conference Organizing Officers}

Jaret J. Frafjord, 2008 Convention General Chair

Frederick Schmidt, Jr., 2009 Convention General Chair

Jeff Stewart, International Metallographic Contest Chair

Alice Kilgo, International Metallographic Contest Local Chair

Erica Corral, Symposia Co-Chair

Ian Davidson, Symposia Co-Chair

Daniel P. Dennies, Symposia Co-Chair

Luther Gammon, Symposia Co-Chair
Bryan Gauntt, Symposia Co-Chair

Allan Lockley, Symposia Co-Chair Gabriel Lucas, Symposia Co-Chair Rick Noecker, Symposia Co-Chair Rob Panaro, Symposia Co-Chair Natalio Saenz, Symposia Co-Chair

Frederick Schmidt, Jr., Symposia Co-Chair

Donald Susan, Symposia Co-Chair 